Terbit online pada laman web jurnal: http://jurnal.iaii.or.id

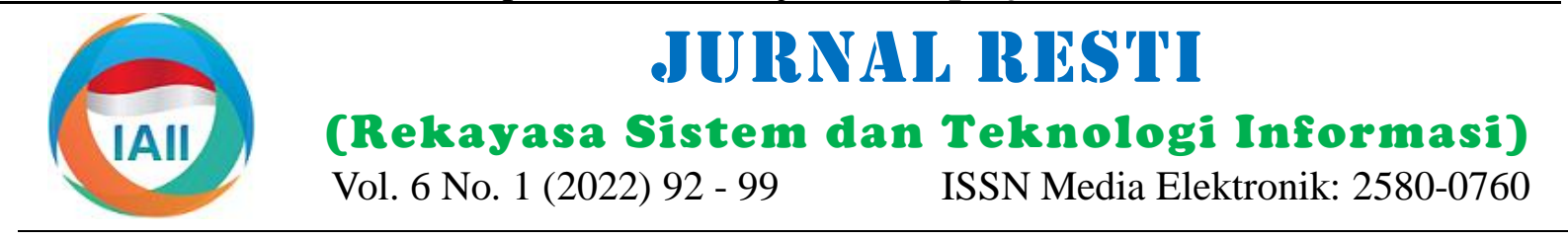

\title{
Gradient Boosting Machine, Random Forest dan Light GBM untuk Klasifikasi Kacang Kering
}

\author{
Indrawata Wardhana ${ }^{1}$, Musi Ariawijaya ${ }^{2}$, Vandri Ahmad Isnaini ${ }^{3}$, Rahmi Putri Wirman ${ }^{4}$ \\ ${ }^{1,2}$ Sistem Informasi, Fakultas Sains dan Teknologi, UIN Sulthan Thaha Saifuddin Jambi \\ ${ }^{3,4}$ Fisika, Fakultas Sains dan Teknologi, UIN Sulthan Thaha Saifuddin Jambi \\ ${ }^{1}$ indrawataw@uinjambi.ac.id, ${ }^{2}$ musi@uinjambi.ac.id, ${ }^{3}$ vandri@uinjambi.ac.id, ${ }^{4}$ rahmi@uinjambi.ac.id
}

\begin{abstract}
Bean seed classification is critical in determining the quality of beans. Previously, the same dataset was tested using the MLP, SVM, KNN, and DT algorithms, with SVM producing the best results. The purpose of this study is to determine the most effective model through the use of the BoxCox transformation selection feature and the random forest (RF) algorithm, as well as the gradient boosting machine (GBM), light GBM, and repeated $k$-folds evaluation model. The bean dataset is available on the UCI Repository website. The BoxCox transformation and repeated $k$-folds improved the classification prediction's accuracy. The model is used in the optimal training phase for a random forest with decision tree parameters 50 and depth 10, a gradient boosting machine model with a learning rate of 1 , and a light gradient boosting machine model with a learning rate of 0.5 and estimator of 500. The best training accuracy results are obtained with light GBM. which is 99 percent accurate, but only 91 percent accurate in terms of validation. According research, the Barbunya, Bombay, Cali, Dermason, Horoz, Seker, and Sira beans classes provided accuracy values of 91 percent, 100 percent, 92 percent, 92 percent, 95 percent, 94 percent, and 84 percent, respectively.
\end{abstract}

Keywords: GBM, RF, LightGBM, Bean Classification, BoxCox

\begin{abstract}
Abstrak
Klasifikasi biji kacang sangat penting dalam penentuan mutu kacang. Dataset yang sama sebelumnya telah diuji menggunakan algoritma MLP, SVM, KNN dan DT, dimana SVM memberikan hasil yang paling baik. Penelitian ini bertujuan untuk melihat model yang paling efektif dengan menggunakan fitur seleksi transformasi BoxCox dan algoritma Random Forest (RF), Gradient Boosting Machine (GBM), light GBM serta model evaluasi repeated k-folds. Dataset kacang berasal dari website UCI Repository. Didapatkan bahwa transformasi BoxCox dan repeated $k$-folds meningkatkan akurasi dari prediksi klasifikasi. Penggunaan pada model pada fase training terbaik untuk random forest dengan paramater pohon keputusan 50 dan depth 10 , model gradient boosting machine pada learning rate 1, dan model light gradient boosting pada learning rate 0,5 dan estimator 500. Light GBM memberikan hasil akurasi training terbaik yakni 99 persen namun akurasi validasi hanya 91 persen. Dari prediksi tersebut, didapatkan hasil bahwa kelas kacang Barbunya, Bombay, Cali, Dermason, Horoz, Seker, dan Sira memberikan nilai akurasi berturut-turut yakni 91\%, 100\%, 92\%, 92\%, 95\%, 94\% dan $84 \%$.
\end{abstract}

Kata kunci: : GBM, RF, Light GBM, klasifikasi kacang, BoxCox

\section{Pendahuluan}

Penentuan klasifikasi biji-bijian merupakan faktor yang penting sekali dalam menentukan mutu biji-bijian dan telah banyak dilakukan dengan berbagai metode oleh para ahli. Beberapa klasifikasi biji menggunakan peralatan laboratorium telah dilakukan yakni menggunakan [1] spektroskopi inframerah, klasifikasi biji kakao dengan analisis kromatografi [2] dan spectrometer inframerah [3]. Untuk meningkatkan hasil analisis klasifikasi, metode penggabungan antara pengukuran laboratorium dan analisa statistik juga dilakukan. Kurniawan dkk menggunakan Near Infrared (NIR) Spektroskopi dalam klasifikasi biji kakau dengan lima spektrum data pretreatment yakni penghalusan, turunan pertama, turunan kedua, Multiple Scatter Correction (MSC), Standard Normal Variate (SNV), dan Principle Component Analysis (PCA) [4] . Klasifikasi biji kakau menggunakan kromatografi analisis yang kemudian diolah datanya menggunakan $k$-means,

Diterima Redaksi: 04-12-2021 | Selesai Revisi: 26-01-2022 | Diterbitkan Online: 27-02-2022 
principal component analysis, dan Discriminant randomforests, LightGBM, dan gradient boosting. Hasil Analysis (DA) dapat mengelompokkan biji tersebut komparasi, diindikasikan bahwa CatBoost merupakan berdasarkan 6 jenis karakteristik kimia [5]. Kemudian hasil terbaik untuk akurasi dan AUC, walaupun penentuan keberlangsungan hidup biji kacang kedelai perbedaannya kecil. Light Gradient Boosting Machine menggunakan Fluorescence hyperspectral imaging (LightGBM) tercepat dari semua metode. Dan (FHSI) dan CARS-SVM-AdaBoost berhasil dideteksi XGBoost menempati posisi kedua untuk akurasi dan dengan akurasi sebesar 100 persen [6]. kecepatan training [23].

Metode analisis serta perhitungan pada machine Light GBM mempercepat waktu proses 20 kali lipat dari learning dan image recognition kacang kering dapat fase pelatihan Gradient Boosting Decision Tree (GBDT) diidentifikasi berdasarkan panjang, bentuk, besar, dan konvensional dengan akurasi yang sama [24]. aspek fisik lainnya. Teknik computer vision juga dapat Penggunaan LightGBM pada pinjaman jaringan p2p, digunakan untuk menentukan klasifikasi sampel seperti dengan hasil yang lebih baik dari XGBoost [25]. Pada membedakan jenis bibit kacang kering[7], klasifikasi prediksi miRNA penderita kanker payudara, warna kulit kacang [8], klasifikasi biji kopi [9][10], biji menggunakan beberapa teknik machine learning yakni kopi dengan ampas [11] menggunakan klusterisasi $k$ - XGBoost, Random Forest, dan lightGBM , diperoleh means.

Ada beberapa teknik identifikasi sampel atau objek pada bahwa LightGBM dari beberapa aspek seperti akurasi dan kecepatan unggul dari dua teknik lainnya [26].

machine learning. Transformasi data BoxCox banyak Pada penelitian ini melakukan komparasi terhadap digunakan pada machine learning. Penggunaan BoxCox akurasi prediksi pada tiga algoritma gradient boosting untuk mengurangi anomali seperti non-additivity, non- machine, random forest dan Light GBM menggunakan normality, dan heteroscedasticity[12]. Metode BoxCox fitur seleksi BoxCox. Komparasi ini akan diuji pada membantu untuk memilih respon tranformasi untuk klasifikasi dataset kacang kering.

meyakinkan validitas data dari sebuah distribusi Gaussian [13]. BoxCox juga membantu peneliti secara 2. Metode Penelitian

cepat untuk mencari transformasi normalisasi yang optimal untuk tiap variabel[14]. Terdapat dua model seleksi dari transformasi dan aplikasi nya pada model regresi linier [15].

Random Forest (RF) banyak digunakan pada klasifikasi dan regresi, dari penelitian diperoleh hasil bahwa model Data berasal dari website UCI Repository Dry Bean RF lebih akurat dari akurasi biomass gandum dataset [27] [7].Tujuh jenis kacang kering digunakan dibandingkan dengan Support Vector Regression (SVR) pada penelitian ini. Fitur yang digunakan seperti bentuk, dan Artificial Neural Network (ANN) pada tiap tahapan, dimensi, tipe dan struktur. Dataset ini juga di lengkapi dan kekokohan sama baiknya dengan SVR, namun lebih dengan gambar dari 7 jenis kacang, namun pada baik dari ANN. Klasifikasi RF digunakan pada penyakit penelitian ini tidak menggunakan dataset gambar getah bening, dengan memadukan fitur seleksi algoritma tersebut, hanya berdasarkan kelas kacang yang tersedia genetik, didapatkan akurasi sebesar 92,2 \% [16][17]. pada kolom ke 17. Klasifikasi terdiri dari 16 fitur, 12 Penggunaan RF dalam mengidentifikasi 23 panjang dimensi, dan 4 bentuk dari permukaan dengan total baris gelombang yang berkaitan dengan struktur tumbuhan sebanyak 13.611. Beberapa variabel yang digunakan dan konten air [18]. Random Forest juga digunakan berurutan dalam dataset yakni:

untuk memprediksi mutasi kanker dari dataset genomic [19]. Akurasi RF sangat akurat sebesar 96,57\% dan AUC besar dari $98 \%$ saat mengenali host tropis dari protein influenza individu [20].

Gradient Boosting Machine (GBM) memiliki beberapa keunggulan dari metode machine learning lain. Penelitian didapatkan bahwa GBM meningkatkan akurasi prediksi R kuadrat dan RMSE lebih dari 80 persen dibandingkan dengan model terbaik industri yakni algoritma random forest dan regresi linier [21]. GBM juga digunakan pada prediksi waktu pergi dan kedatangan, dimana GBM memiliki kelebihan untuk prediksi waktu keberangkatan yang bebas memilih [22]. Beberapa keluarga dari algoritma gradient boosting diuji pada kecepatan dan akurasi. Uji dilakukan pada CatBoost, eXtreme Gradient Boosting (XGBoost),
1. Area (A)
2. Perimeter $(\mathrm{P})$
3. Panjang sumbu utama (L)
4. Panjang sumbu minor (l)
5. Aspek rasio $(\mathrm{K})$
6. Eksentrisitas (Ec)
7. Area cembung (C)
8. Diameter ekuivalen (Ed)
9. Luas (Mis)
10. Soliditas $(\mathrm{S})$
11. Kebulatan (R)
12. Compactness $(\mathrm{CO}$
13. Faktor Bentuk1 (SF1)
14. Faktor Bentuk2 (SF2)
15. Faktor Bentuk3 (SF3)
16. Faktor Bentuk4 (SF4)

DOI: https://doi.org/10.29207/resti.v5i1.3682

Lisensi: Creative Commons Attribution 4.0 International (CC BY 4.0) 
17. Kelas kacang (Barbunya, Bombay, Dermosan, $f(x)=\sum_{b=1}^{B} f^{b}(x)$

Horoz ,Seker, Cali dan Sira).

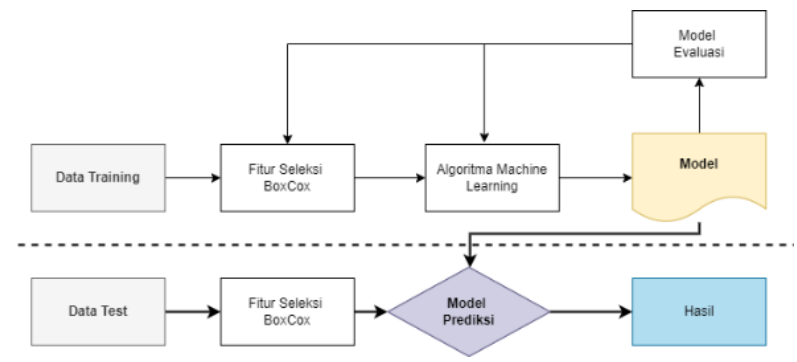

Gambar 1. Flowchart Metode Klasifikasi

Korelasi pearson digunakan untuk melihat hubungan antara variabel. Dimana koofisien korelasi Pearson memiliki perumusan berikut ini.

$$
\text { Pearson }=\frac{\operatorname{cov}(x, y)}{\operatorname{stdev}(c) x \operatorname{stdev}(y)}
$$

Dimana cov merupakan covarian, stdev adalah standar untuk mengetahui kinerja dari tiap algoritma.

deviasi. Untuk menginterprestasi koofisien korelasi Evaluasi menggunakan confusion matrix yang terdiri tersebut dapat dilihat pada tabel berikut :

Tabel 1.Tabel nilai koofisen korelasi dan interprestasi

\begin{tabular}{ccc}
\hline Korelasi Lansung & $\begin{array}{c}\text { Korelasi tidak } \\
\text { lansung }\end{array}$ & Kekuatan Relasi \\
\hline 0.0 & 0.0 & Tidak ada \\
0.1 & -0.1 & Lemah/kecil \\
0.3 & -0.3 & Menengah \\
0.5 & -0.5 & Kuat \\
1.0 & -1.0 & Terbaik \\
\hline
\end{tabular}

\subsection{Algoritma Klasifikasi}

Proses prediksi pada tes dataset menggunakan Random forest, Gradient Boosting Machine dan Light Gradient Boosting Machine.

Pada klasifikasi Random forest digunakan Gini Index sebagai atribut pengukuran seleksi dimana mengukur ketidakmurnian dari atribut yang berkaitan dengan kelas. Untuk training set $\mathrm{T}$, seleksi satu kasus (piksel)
dengan acak dan itu berhubungan dengan beberapa kelas Ci. Gini index dapat di tulis dalam rumusan 2 [28] berikut ini :

$$
\sum \sum_{j \neq i}\left(f\left(C_{i}, T\right) /|T|\right)\left(f\left(C_{j}, T\right) /|T|\right)
$$

dimana $\mathrm{f}(\mathrm{Ci}, \mathrm{T}) / \mathrm{T} \mid$ merupakan probabilitas dari dari seleksi kasus yang berhubungan dengan kelas Ci. Setiap perkembangan dari pohon menuju kedalaman maksimum pada setiap pelatihan data menggunakan kombinasi fitur.

Klasifikasi GBM tujuan nya adalah mencari model additive yang meniminalkan fungsi loss [21]. Persamaan algortima untuk meningkatkan regresi trees dapat digeneralkan pada persamaan 3, dimana model akhir dari model penambahan bertahap sederhana dari nilai $b$

\subsection{Normalisasi data BoxCox}

BoxCox berfungsi sebagai transformasi pada data tidak normal yang kemudian diubah menjadi bentuk normal. Normalitas merupakan asumsi penting pada berbagai teknik statistik. Transformasi ini dilakukan dengan menggunakan estimasi kemungkinan maksimum untuk mengestimasi eksponen daya lambda, dimana nilainya berkisar antara -5 dan 5 . Persamaannya dapat dilihat sebagai berikut.

$$
y(\lambda)=\left\{\begin{array}{l}
\frac{y^{\lambda}-1}{\lambda} \text { jika } \lambda \neq 0 \\
\log y \text { jika } \lambda=0
\end{array}\right.
$$

Dimana lambda merupakan nilai antara -5 dan 5 .

\subsection{Evaluasi}

Tahapan evaluasi terhadap metode klasifikasi dilakukan dari tujuh kelas yakni Barbunya, Bombay, Cali, Dermason, Horoz, Seker, dan Sira. Adapun confusion matrix untuk kelas kacang kering tersebut ditunjukkan pada Tabel 2.

Tabel 2.Confusion Matrix Kelas Kacang

\begin{tabular}{ccc}
\hline Eksperimen & \multicolumn{2}{c}{ Kelas Prediksi } \\
\hline Kelas Aktual & Positif & Negatif \\
\hline Positif & TP & TN \\
Negatif & FP & FN \\
\hline
\end{tabular}

Dimana TN, FN , TP dan FP merupakan kependekan dari true negative, false negative, true positive dan false positive

Pada tahapan ini, metode yang digunakan adalah $k$-fold repeated cross-validation dalam mengevaluasi performa klasifikasi dataset training dan test. Pengulangan dilakukan sebanyak n kali untuk 10 k-fold sesuai persamaan 5 .

$$
E=\frac{1}{10} \sum_{i=1}^{10} E_{i}
$$

dimana E merupakan error dari setiap iterasi. Iterasi dari tiap fold dapat di gambarkan pada gambar 2 .

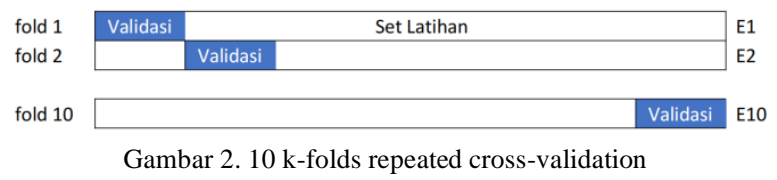

Precision, recall, dan $f 1$ score digunakan sebagai metrik dalam evaluasi performa dari klasifikasi. Metrik tersebut diformulasikan pada rumus 6 dan 7 .

$$
\begin{aligned}
& \text { Precision }=\frac{T P}{T P+F P} \times 100 \% \\
& \text { Recall }=\frac{T P}{T P+F N} \times 100 \%
\end{aligned}
$$




$$
f 1=\frac{\left(1+\beta^{2}\right) \times \text { precision } \times \text { recall }}{\left(\beta^{2} \times \text { precision }\right)+\text { recall }} \times 100 \%
$$

\subsection{Peralatan}

Penelitian ini menggunakan hardware spesifikasi teknis sebagai berikut : Intel VGA HD Graphics 3000, Processor Intel i5, SSHD $1 \mathrm{~Tb}$, dan RAM DDR3 8 Gb. Pengolahan data menggunakan bahasa Python dan $\mathrm{R}$ dengan menggunakan software Anaconda Jupyter berbasis web.

\section{Hasil dan Pembahasan}

\subsection{Korelasi Variabel}

Dataset diolah terlebih dahulu menjadi data latih dan data uji. Pembagiannya menjadi tiga bagian yakni: 70:30,80:20, dan 90:10 dengan porsi terbesar pada data latih. Pengecekan nilai kosong dilakukan pada dataset, dimana tidak terdapat data kosong. Hubungan antar variabel pada dataset dianalisis dengan persamaan Pearson. Hubungan antar variabel tersebut dapat dilihat pada Gambar 3. Hubungan terdiri dari relasi langsung dan relasi tidak langsung. Hubungan langsung berada pada kisaran $0-1$ dan tidak lansung antara 0 dan -1 . Beberapa variabel memiliki hubungan langsung di atas 0.5 yakni Area, Perimeter, MajorAxisLength, MinorAxisLength, ConvexArea, EquivDiameter, dan Compacness. Korelasi tidak langsung di bawah -0.5 yakni variabel: Compactness, ShapeFactor 1, ShapeFactor2. Jumlah kelas kacang berdasarkan jenisnya yakni: Barbunya 1322, Bombay 522, Cali 1630, Dermason 3546, Horoz 1928, Seker 2027, dan Sira 2636.

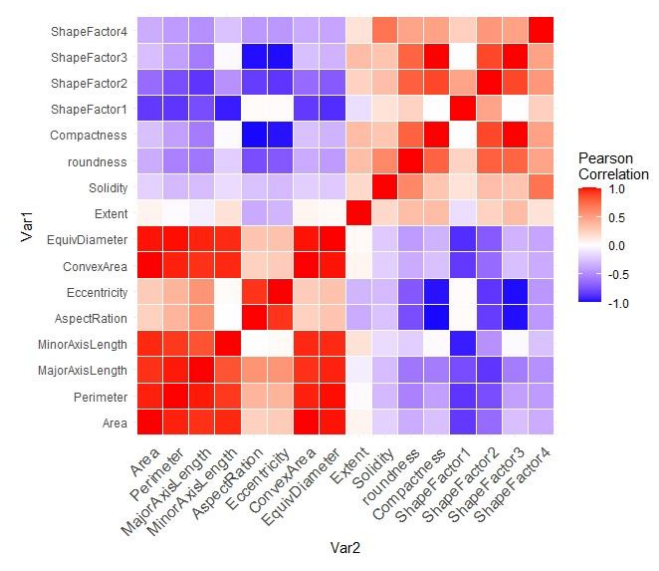

Gambar 3. Korelasi Pearson antar variabel

Dari Gambar 4, didapatkan hanya beberapa variabel saja yang nilainya terdistribusi normal yakni ShapeFactor1, ShapeFactor2, ShapeFactor3, dan Compactness yang memiliki skewness simetris. Sedangkan skewness positif terdapat pada variabel:
Area, Perimeter, MinorAxisLength. Berbeda dengan variabel: Eccentricy, Extent, Solidity, Roundness, dan ShapeFactor4 memiliki skewness negatif. Leptokurtic hanya terjadi pada variabel: Perimeter dan EquivDiameter.

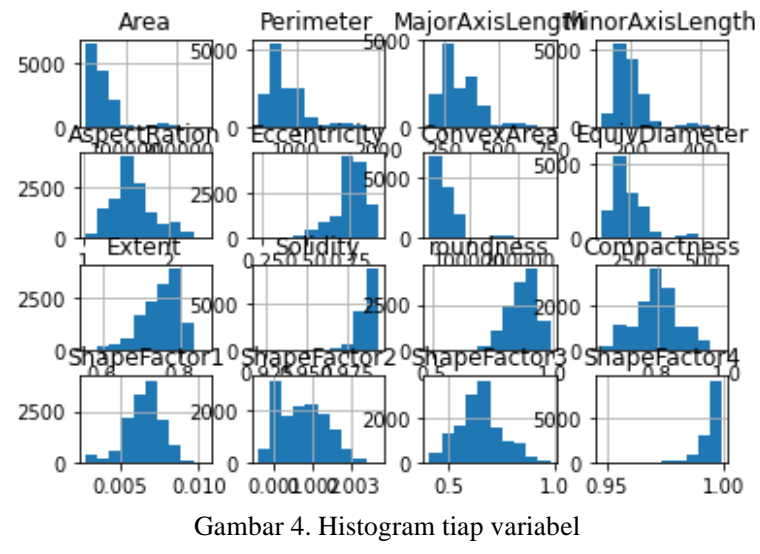

3.2. Model Training

Pada tahapan ini dilakukan fase training dengan menggunakan model training Random Forest, Gradient Boosting Machine, dan Light GBM (LGB). Pembagian data latih dan validasi yang baik dengan membagi data menjadi tiga yakni porsi dari data latih $70 \%, 80 \%$, dan $90 \%$.

Tabel 3.Akurasi dan data latih

\begin{tabular}{ccc}
\hline Persentase & Model & Akurasi \\
\hline 70 persen & RF & 0.917184 \\
70 persen & GBM & 0.919074 \\
70 persen & LGB & 0.918758 \\
80 persen & RF & 0.917626 \\
80 persen & GBM & 0.918076 \\
80 persen & LGB & 0.918076 \\
90 persen & RF & 0.917626 \\
90 persen & GBM & 0.917789 \\
90 persen & LGB & 0.919340 \\
\hline
\end{tabular}

Sembilan data yang diperoleh hasil pelatihan, didapatkan bahwa rata-rata akurasi berada pada nilai 0.91. Namun nilai akurasi terbaik menggunakan LGB. Pelatihan dilakukan menggunakan default model pelatihan tanpa ada penambahan hyperparameter.

\subsection{BoxCox Repeated k-folds}

Pada tahapan ini, dataset divalidasi menggunakan repeated 10-folds sebanyak 3 kali. Dataset tidak dilakukan transformasi menggunakan BoxCox. Pada Gambar 5, dapat dilihat bahwa pada pengulangan pertama didapatkan bahwa rata-rata berada di 0.925 dan quartile 1 tidak mencapai 0.935 . Terjadi penurunan pada pengulangan ke-tiga, walau tidak terlalu signifikan. Dari pengulangan tiga kali, tidak terdapat quartile 1 mencapai akurasi 93,5 persen. 


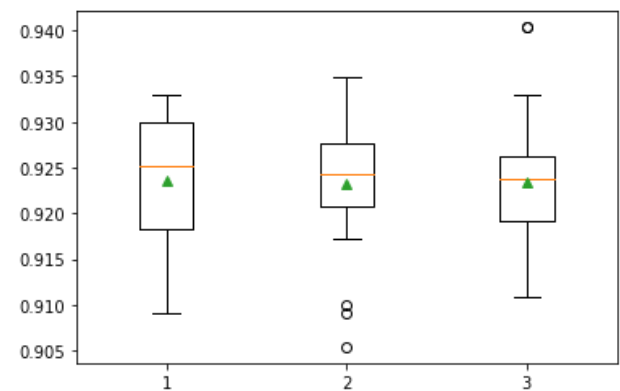

Gambar 5. Sebelum BoxCox 3 Repeated 10-folds.

Penerapan transformasi BoxCox pada dataset ternyata dapat meningkatkan akurasi dari klasifikasi. Pada Gambar 6, terlihat bahwa hampir semua validasi 10folds menunjukkan nilai quartile 1 yang mencapai $94 \%$. Dimana terjadi kenaikan nilai rata-rata akurasi setiap terjadi pengulangan validasi.

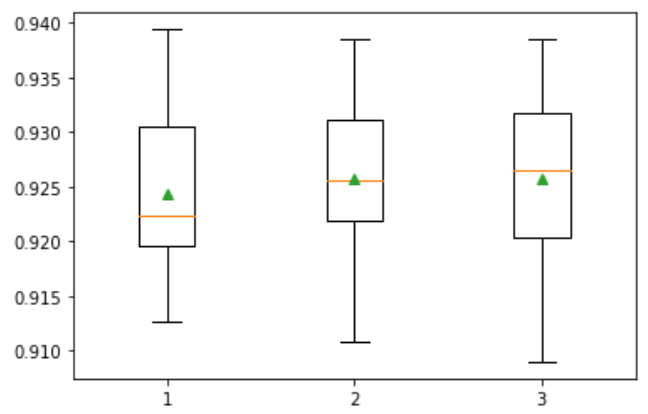

Gambar 6. Setelah BoxCox 3 Repeated 10-folds.

\subsection{Random Forest}

Salah satu parameter untuk optimasi dari metode Random Forest adalah jumlah pohon. Pada uji latihan dengan jumlah pohon 10, 50, 100, 500, dan 1000 didapatkan akurasi rata-rata sebesar 91,4, 92, 92, 92,1, dan 92,2 persen. Dimana nilai akurasi stabil pada jumlah pohon lebih dari 50 buah. Hubungan antara akurasi dan jumlah pohon dapat dilihat pada Gambar 7.

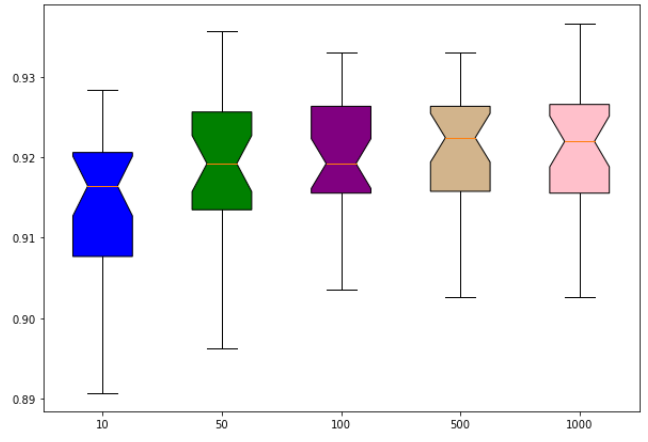

Gambar 7. Akurasi vs Jumlah Pohon berbeda $0.001-0.003$. Akurasi terbaik bernilai 92.46 persen. Hubungan antara akurasi dan prediktor dapat dilihat pada Gambar 8.

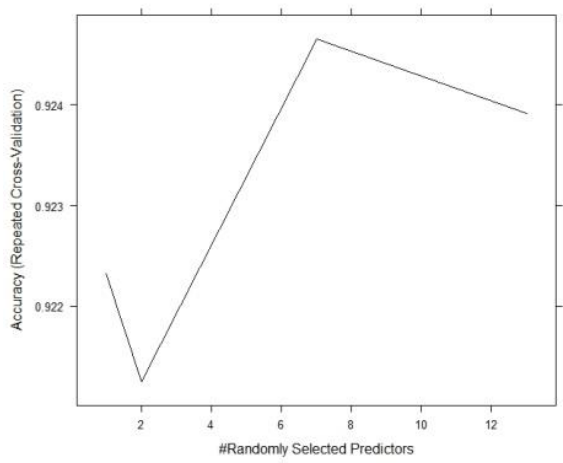

Gambar 8. Akurasi vs jumlah prediktor

Hasil training pertama menunjukkan jumlah pohon keputusan sebanyak 50 untuk tahapan latihan berikutnya. Pada tahapan ini dilakukan variasi parameter depth dari 1 hingga 11. Dari Gambar 9, dapat dilihat bahwa hasil akurasi train dan validasi yang sama-sama naik drastis terhenti pada depth $=7$, dimana nilai nya sebesar 0.919177 dan 0.901579. Pada depth ke 8 hingga 11, nilai akurasi train naik terus hingga 0.966936 , namun nilai akurasi validasi stabil di angka 0.91 . Akurasi validasi tertinggi pada depth 10 yakni 0.914433 . Setelah depth 11, nilai validasi turun. Nilai train dan validasi terendah berada di depth $=1$ yakni hanya bernilai 0.535911 dan 0.537642. Dengan demikian, maka untuk prediksi klasifikasi diambil parameter jumlah pohon 50 dan depth 10.

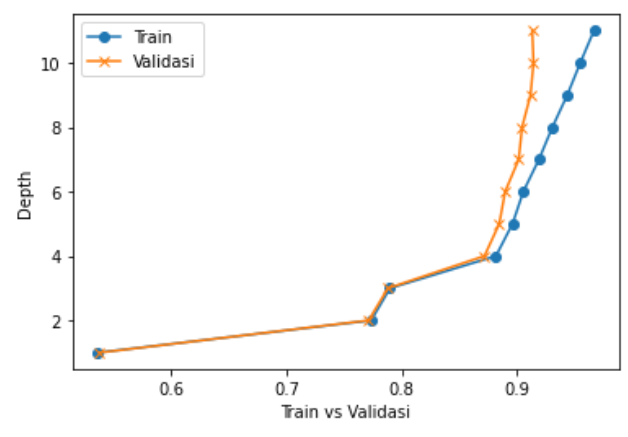

Gambar 9. RF dengan variasi depth.

Tabel 4, diperoleh akurasi tertinggi pada kacang kelas Bombay dengan presisi 1.00 dan recall 1.00. Hal ini dikarenakan jumlah kelas Bombay paling kecil, sehingga model lebih mudah dalam melakukan prediksi. Walaupun demikian, berdasarkan pada Tabel 7, volume kelas tertinggi terdapat pada Dermason tapi nilai akurasi Jumlah prediktor menurut beberapa penelitian dapat nya mencapai 0,92 tidak begitu jauh dengan hasil kelas mempengaruhi hasil dari akurasi random forest. Untuk yang lain. Sedangkan yang terburuk terdapat pada kelas itu dari 16 prediktor dengan 10.891 baris dan 7 kelas, Sira. Sedangkan nilai sensitivitas (recall) terendah dilakukan seleksi acak terhadap prediktor tersebut. berada pada Barbuya yakni 0.88 persen , dimana nilai Didapatkan bahwa prediktor terbaik sebanyak 7 FN nya bernilai besar. Disisi lain, presisinya bernilai variabel. Dengan nilai yang tidak terlalu beda, hanya 0.94 .

DOI: https://doi.org/10.29207/resti.v5i1.3682

Lisensi: Creative Commons Attribution 4.0 International (CC BY 4.0) 
Tabel 4.Nilai Presisi, Recall dan f1-score RF

\begin{tabular}{llll}
\hline Kelas & Presisi & Recall & f1-score \\
\hline Barbunya & 0.94 & 0.88 & 0.91 \\
Bombay & 1.00 & 1.00 & 1.00 \\
Cali & 0.92 & 0.96 & 0.94 \\
Dermason & 0.92 & 0.90 & 0.91 \\
Horoz & 0.95 & 0.95 & 0.95 \\
Seker & 0.93 & 0.92 & 0.93 \\
Sira & 0.83 & 0.86 & 0.84 \\
\hline
\end{tabular}

Didapatkan juga bahwa nilai kappa sebesar 0.89. Nilai ini mendekati 1, menandakan bahwa nilai koefisiennya menunjukan terdapat korelasi. Tabel 7 dan 8, pada confusion matrix Random Forest dan GBM memiliki hasil yang mirip, yakni pada hampir semua kesalahan yang terjadi. Kesalahn tersebar dalam prediksi terjadi pada kelas kacang Sira.

\subsection{GBM}

Pelatihan GBM dengan parameter learning rate (lr) digunakan untuk optimasi model training. Variasi nilai learning rate berkisar antara 0 -1. Gambar 10 tampak bahwa nilai validasi lebih rendah dari nilai train pada $\mathrm{lr}$ 0.05 . Terdapat perbedaan yang tajam pada lr 1.0, dimana nilai train sebesar 0.93 dan nilai validitas 0.91 .

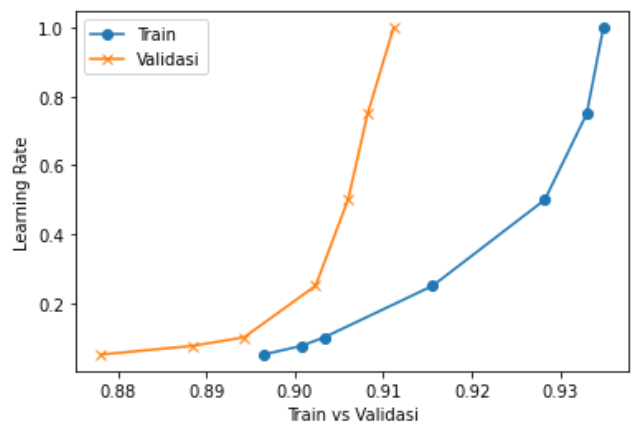

Gambar 10. Learning Rate pada GBM

Pada Tabel 5, diperoleh kembali akurasi tertinggi pada kacang kelas Bombay dengan presisi 1.00 dan recall 1.00. Berdasarkan Tabel 8, volume kelas tertinggi terdapat pada Dermason tapi nilai akurasi nya sama dengan prediksi pada RF yakni 0,92, namun recall (sensivitas) nya lebih rendah. Sedangkan yang terkecil, masih terdapat pada kelas Sira. Sedangkan nilai sensitivitas (recall) pada Barbuya naik senilai 92 persen, dimana tersebut lebih besar dari model RF.

Tabel 5. Nilai Presisi, Recall dan f1-score GBM

\begin{tabular}{llll}
\hline Kelas & Presisi & Recall & f1-score \\
\hline Barbunya & 0.91 & 0.92 & 0.92 \\
Bombay & 1.00 & 1.00 & 1.00 \\
Cali & 0.94 & 0.95 & 0.95 \\
Dermason & 0.92 & 0.89 & 0.90 \\
Horoz & 0.94 & 0.95 & 0.95 \\
Seker & 0.93 & 0.93 & 0.93 \\
Sira & 0.83 & 0.86 & 0.84 \\
\hline
\end{tabular}

DOI: https://doi.org/10.29207/resti.v5i1.3682

Lisensi: Creative Commons Attribution 4.0 International (CC BY 4.0)

\subsection{Light GBM}

Fase training LGB, digunakan learning rate yang bervariasi antara 0 hingga 1 . Nilai lr yakni $0.01,0.02$, 0.05, 0.08, 0.2, 0.5, dan 0.6. Terlihat pada Gambar 11, tampak bahwa terjadi penurunan tajam akurasi train dan validitas pada lr 0.6. Sebelumnya nilai train sebesar 0.967 pada lr 0.5 langsung turun menjadi 0.66 dan juga nilai validasi dari 0.90 menjadi 0.65 . Nilai validitas tertinggi pada lr 0.20 yakni sebesar 0.907 .

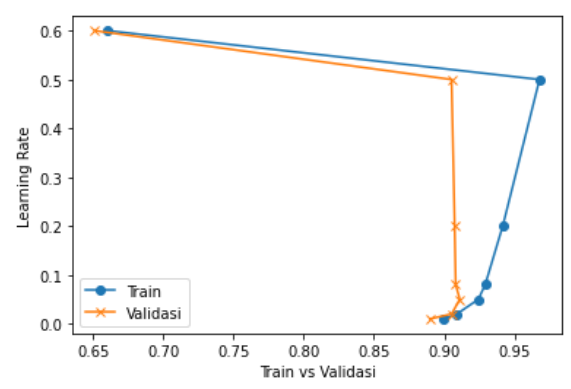

Gambar 11. Learning Rate pada LGB

Proses ini mendapatkan nilai lr terbaik yakni 0.2 , maka fase training dilanjutkan dengan menggunakan parameter n_estimator. Penelitian ini didapatkan hasil yang signifikan berbeda antara nilai akurasi train dan validasi. Seperti tampak pada Gambar 12, bahwa pada n_estimator 100 nilai akurasi train dan validasi yakni 0.96 dan 0.90. Didapatkan bahwa fase train hampir mencapai angka satu yakni bernilai 0.999755 pada n_estimator 500. Namun pada akurasi validasi, nilai nya hanya berkisar 0.91 .

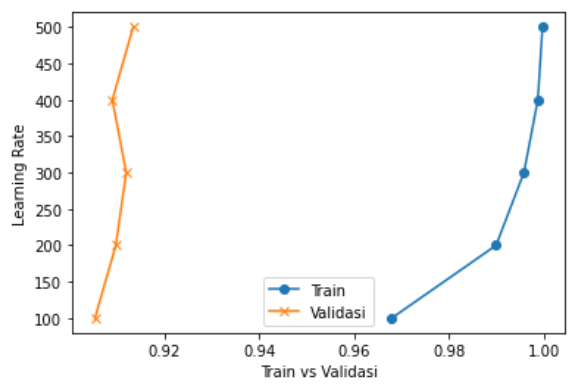

Gambar 12.n_estimator pada LGB

Tampak pada Tabel 6, nilai akurasi pada tiap kelas tidak mengalami perbedaan signifikan pada model training sebelumnya yakni RF dan GBM. Pada Tabel 9, terlihat kesalahan dalam menentukan kelas kacang tertinggi ada pada kelas kacang Sira.

Tabel 6. Nilai Presisi, Recall dan f1-score GBM

\begin{tabular}{llll}
\hline Kelas & Presisi & Recall & f1-score \\
\hline Barbunya & 0.91 & 0.90 & 0.91 \\
Bombay & 1.00 & 1.00 & 1.00 \\
Cali & 0.92 & 0.95 & 0.93 \\
Dermason & 0.92 & 0.90 & 0.90 \\
Horoz & 0.95 & 0.94 & 0.94 \\
Seker & 0.94 & 0.92 & 0.93 \\
Sira & 0.84 & 0.86 & 0.85 \\
\hline
\end{tabular}


Tabel 7. Confusion Matrix Random Forest

\begin{tabular}{lccccccc}
\hline Confusion & Barbuya & Bombay & Cali & Dermason & Horoz & Seker & Sira \\
\hline Barbunya & 133 & 0 & 8 & 0 & 2 & 0 & 1 \\
Bombay & 0 & 33 & 0 & 0 & 0 & 0 & 0 \\
Cali & 5 & 0 & 164 & 0 & 1 & 0 & 2 \\
Dermason & 1 & 0 & 0 & 333 & 2 & 7 & 33 \\
Horoz & 3 & 0 & 1 & 2 & 184 & 0 & 4 \\
Seker & 3 & 0 & 0 & 4 & 0 & 171 & 6 \\
Sira & 1 & 0 & 1 & 22 & 6 & 6 & 223 \\
\hline
\end{tabular}

Tabel 8. Confusion Matrix Gradient Boosting Machine

\begin{tabular}{lccccccc}
\hline Confusion & Barbuya & Bombay & Cali & Dermason & Horoz & Seker & Sira \\
\hline Barbunya & 130 & 0 & 12 & 0 & 0 & 0 & 2 \\
Bombay & 0 & 33 & 0 & 0 & 0 & 0 & 0 \\
Cali & 5 & 0 & 163 & 0 & 2 & 0 & 2 \\
Dermason & 0 & 0 & 0 & 340 & 2 & 4 & 30 \\
Horoz & 4 & 0 & 2 & 1 & 182 & 0 & 5 \\
Seker & 3 & 0 & 0 & 7 & 0 & 170 & 4 \\
Sira & 1 & 0 & 1 & 21 & 6 & 6 & 224 \\
\hline
\end{tabular}

Tabel 9. Confusion Matrix Light GBM

\begin{tabular}{lccccccc}
\hline Confusion & Barbuya & Bombay & Cali & Dermason & Horoz & Seker & Sira \\
\hline Barbunya & 127 & 0 & 12 & 0 & 2 & 0 & 3 \\
Bombay & 0 & 33 & 0 & 0 & 0 & 0 & 0 \\
Cali & 2 & 0 & 165 & 0 & 3 & 0 & 2 \\
Dermason & 0 & 0 & 0 & 338 & 0 & 6 & 32 \\
Horoz & 4 & 0 & 0 & 2 & 184 & 0 & 4 \\
Seker & 1 & 0 & 1 & 6 & 0 & 170 & 6 \\
Sira & 1 & 0 & 2 & 23 & 5 & 6 & 222 \\
\hline
\end{tabular}

\section{Kesimpulan}

Penggunaan model transform BoxCox dapat meningkatkan akurasi dari klasifikasi, walau perbedaan secara nilai tidak terlalu besar jika tanpa menggunakan BoxCox. Untuk prediksi klasifikasi dengan nilai False Negatif terkecil terdapat pada model training GBM, walau demikian nilai recall secara rata-rata tidak terlalu signifikan perbedaan dengan model lain. Jika ingin mendapatkan prediksi dengan salah, artinya lebih sedikit salah dalam memprediksi kelas dari kacang.

RF, GBM, dan LGB memiliki hasil prediksi klasifikasi kelas yang hampir sama. Namun dalam fase training, memiliki perbedaan yang cukup signifikan. RF memiliki kemampuan akurasi training hingga 96\%, GBM hanya mampu pada angka 93 persen, sedangkan LGB yang awalnya terjadi penurunan tajam pada parameter learning rate namun pada parameter estimator mampu mencapai 99,9 persen. Nilai akurasi pada tiap kelas berbeda, namun prediksi terbaik terjadi pada kelas kacang Bombay sedangkan prediksi terburuk terjadi pada kelas kacang Sira. Proses prediksi ini didapatkan hasil bahwa kelas kacang Barbunya, Bombay, Cali, Dermason, Horoz, Seker, dan Sira memberikan nilai akurasi berturut-turut yakni 91\%, 100\%, 92\%, 92\%, $95 \%, 94 \%$ dan $84 \%$.

\section{Daftar Rujukan}

[1] D. F. Barbin et al., "Classification and compositional characterization of different varieties of cocoa beans by near infrared spectroscopy and multivariate statistical analyses," J. Food Sci. Technol. 2018 557, vol. 55, no. 7, pp. 2457-2466,
Apr. 2018.

https://doi.org/10.1007/s13197-018-3163-5

[2] R. Megías-Pérez, S. Grimbs, R. N. D'Souza, H. Bernaert, and N Kuhnert, "Profiling, quantification and classification of cocoa beans based on chemometric analysis of carbohydrates using hydrophilic interaction liquid chromatography coupled to mass spectrometry," Food Chem., vol. 258, pp. 284-294, Aug. 2018.

https://doi.org/10.1016/j.foodchem.2018.03.026

[3] A. J. Myles, S. D. Brown, and T. A. Zimmerman, "Transfer of Multivariate Classification Models Between Laboratory and Process Near-Infrared Spectrometers for the Discrimination of Green Arabica and Robusta Coffee Beans," Appl. Spectrosc. Vol. 60, Issue 10, pp. 1198-1203, vol. 60, no. 10, pp. 11981203, Oct. 2006 https://doi.org/10.1366/000370206778664581

[4] F. Kurniawan, I. W. Budiastra, Sutrisno, and S. Widyotomo, "Classification of Arabica Java Coffee Beans Based on Their Origin using NIR Spectroscopy," IOP Conf. Ser. Earth Environ. Sci., vol. 309, no. 1, p. 012006, Sep. 2019. https://doi.org/10.1088/1755-1315/309/1/012006

[5] A. Vázquez-Ovando, F. Molina-Freaner, J. Nuñez-Farfán, D. Betancur-Ancona, and M. Salvador-Figueroa, "Classification of cacao beans (Theobroma cacao L.) of southern Mexico based on chemometric analysis with multivariate approach," Eur. Food Res. Technol. 2015 2406, vol. 240, no. 6, pp. 11171128, Feb. 2015

https://doi.org/10.1007/s00217-015-2415-0

[6] Y. Li, J. Sun, X. Wu, Q. Chen, B. Lu, and C. Dai, "Detection of viability of soybean seed based on fluorescence hyperspectra and CARS-SVM-AdaBoost model," J. Food Process. Preserv., vol. 43, no. 12, p. e14238, Dec. 2019. https://doi.org/10.1111/jfpp.14238

[7] M. Koklu and I. A. Ozkan, "Multiclass classification of dry beans using computer vision and machine learning techniques," Comput. Electron. Agric., vol. 174, p. 105507, Jul. 2020. https://doi.org/10.1016/j.compag.2020.105507 
[8] S. A. Araújo, W. A. L. Alves, P. A. Belan, and K. P. Anselmo, "A Computer Vision System for Automatic Classification of Most Consumed Brazilian Beans," Lect. Notes Comput. Sci. (including Subser. Lect. Notes Artif. Intell. Lect. Notes Bioinformatics), vol. 9475, pp. 45-53, Dec. 2015. https://doi.org/10.1007/978-3-319-27863-6_5

[9] E. M. De Oliveira, D. S. Leme, B. H. G. Barbosa, M. P. Rodarte, and R. G. F. Alvarenga Pereira, "A computer vision system for coffee beans classification based on computational intelligence techniques," J. Food Eng., vol. 171, pp. 22-27, Feb. 2016. https://doi.org/10.1016/j.jfoodeng.2015.10.009

[10] F. A. Santos, A. M. P. Canuto, B. R. C. Bedregal, E. S. Palmeira, and I. N. P. Silva, "Supervised Methods Applied to the Construction of a Vision System for the Classification of Cocoa Beans in the Cut-Test," An. do Encontro Nac. Inteligência Artif. e Comput., pp. 72-83, Oct. 2019

[11] A. J. Ona Ona, F. Grijalva, K. Proano, B. Acuna, and M. Garcia, "Classification of fresh cocoa beans with pulp based on computer vision," 2020 IEEE ANDESCON, ANDESCON 2020, Oct. 2020. https://doi.org/10.1109/ANDESCON50619.2020.9272188

[12] R. M. Sakia, "The Box-Cox transformation technique: a review," J. R. Stat. Soc. Ser. D ..., 1992. https://doi.org/10.2307/2348250

[13] M. J. Gurka, L. J. Edwards, K. E. Muller, and L. L. Kupper, "Extending the Box-Cox transformation to the linear mixed model," J. R. Stat. Soc. Ser. A (Statistics Soc., vol. 169, no. 2, pp. 273-288, Mar. 2006. https://doi.org/10.1111/j.1467-985X.2005.00391.x

[14] J. Osborne, "Improving your data transformations: Applying the Box-Cox transformation," Pract. Assessment, Res. ..., 2010.

[15] M. Z. Hossain, "The use of Box-Cox transformation technique in economic and statistical analyses," J. Emerg. Trends Econ. $\ldots, 2011$.

[16] L. Wang, X. Zhou, X. Zhu, Z. Dong, and W. Guo, "Estimation of biomass in wheat using random forest regression algorithm and remote sensing data," Crop J., vol. 4, no. 3, pp. 212-219, Jun. 2016 https://doi.org/10.1016/j.cj.2016.01.008

[17] A. T. Azar, H. I. Elshazly, A. E. Hassanien, and A. M. Elkorany, "A random forest classifier for lymph diseases," Comput. Methods Programs Biomed., vol. 113, no. 2, pp. 465-473, Feb. 2014.

https://doi.org/10.1016/j.cmpb.2013.11.004

[18] S. Vitrack-Tamam et al., "Random Forest Algorithm Improves Detection of Physiological Activity Embedded within Reflectance Spectra Using Stomatal Conductance as a Test Case," Remote Sens. 2020, Vol. 12, Page 2213, vol. 12, no.
14, p. 2213, Jul. 2020.

https://doi.org/10.3390/rs12142213

[19] S. Agajanian, O. Oluyemi, and G. M. Verkhivker, "Integration of random forest classifiers and deep convolutional neural networks for classification and biomolecular modeling of cancer driver mutations," Front. Mol. Biosci., vol. 6, no. JUN, p. 44, 2019. https://doi.org/10.3389/fmolb.2019.00044

[20] C. L. Eng, J. C. Tong, and T. W. Tan, "Predicting host tropism of influenza A virus proteins using random forest," BMC Med. Genomics, vol. 7, no. 3, pp. 1-11, Dec. 2014. https://doi.org/10.1186/1755-8794-7-S3-S1

[21] S. Touzani, J. Granderson, and S. Fernandes, "Gradient boosting machine for modeling the energy consumption of commercial buildings," Energy Build., vol. 158, pp. 1533-1543, Jan. 2018. https://doi.org/10.1016/j.enbuild.2017.11.039

[22] Y. Zhang and A. Haghani, "A gradient boosting method to improve travel time prediction," Transp. Res. Part C Emerg. Technol., vol. 58, pp. 308-324, Sep. 2015. https://doi.org/10.1016/j.trc.2015.02.019

[23] C. Bentéjac, A. Csörgő, and G. Martínez-Muñoz, "A comparative analysis of gradient boosting algorithms," Artif. Intell. Rev. 2020 543, vol. 54, no. 3, pp. 1937-1967, Aug. 2020. https://doi.org/10.1007/s10462-020-09896-5

[24] G. Ke et al., "LightGBM: A Highly Efficient Gradient Boosting Decision Tree," Adv. Neural Inf. Process. Syst., vol. 30, 2017.

[25] X. Ma, J. Sha, D. Wang, Y. Yu, Q. Yang, and X. Niu, "Study on a prediction of $\mathrm{P} 2 \mathrm{P}$ network loan default based on the machine learning LightGBM and XGboost algorithms according to different high dimensional data cleaning," Electron. Commer. Res. Appl., vol. 31, pp. 24-39, Sep. 2018. https://doi.org/10.1016/j.elerap.2018.08.002

[26] D. Wang, Y. Zhang, and Y. Zhao, "LightGBM: An effective miRNA classification method in breast cancer patients," ACM Int. Conf. Proceeding Ser., pp. 7-11, Oct. 2017. https://doi.org/10.1145/3155077.3155079

[27] "UCI Machine Learning Repository: Dry Bean Dataset Data Set." [Online]. Available: https://archive.ics.uci.edu/ml/datasets/Dry+Bean+Dataset. [Accessed: 26-Nov-2021].

[28] M. Pal, "Random forest classifier for remote sensing classification," http://dx.doi.org/10.1080/01431160412331269698, vol. 26, no. 1, pp. 217-222, Jan. 2007. https://doi.org/10.1080/01431160412331269698 